\title{
כyorrede.
}

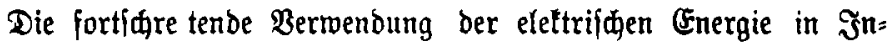
Duffrie und Bemerbe ftellt täglid vermefyrte und erböhte $\mathfrak{A}$ nforberungen

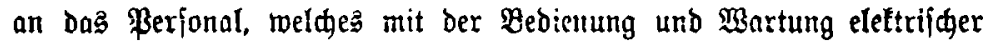

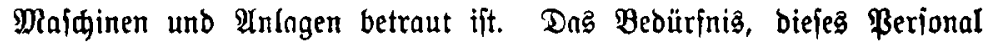
über ferne Ebliegentgeiten jachgentäß zul unterrifften, ift fđjon lange herborgetreten und hat an bielen. Stellen zur Sinridtung bon bahin

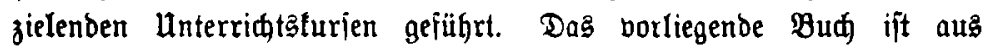

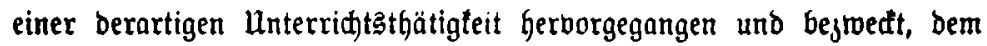

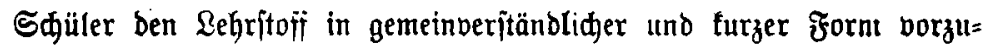

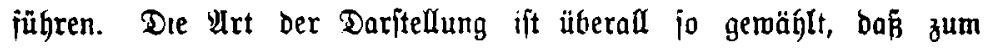

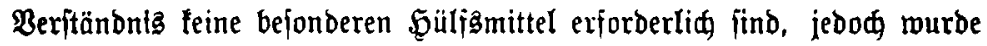

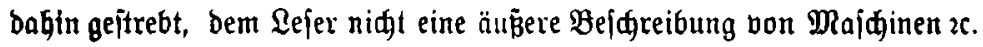
zu geben, foltbern ihm einen tiejeren Einblid in Dent Segenftand zu ermögliden, inşbefondere ifm ein Berftänonis bavon zu beridaffen, wie gegenwärtig bie eleftrifde Energie erzeugt unb verwandt wirb.

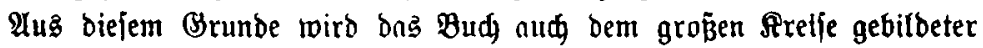
Eaien, velde bns Bedürfinis nad einer Unterweifung auf bem Bebiete

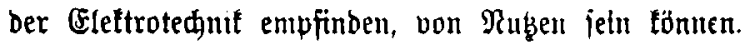

Aađen, im Mpril 1901.

\section{Der Berfalier.}


